\title{
Estimation of Burned Areas In Forest Fires Using Artificial Neural Networks
}

Estimación de áreas quemadas en incendios forestales utilizando redes neurales artificiales

\section{Estimativa de áreas queimadas em incêndios florestais usando redes neurais artificiais}

\author{
M. Hanefi Calp ${ }^{1}$ \\ Utku Kose ${ }^{2}$
}

Received: May $7^{\text {th }}, 2020$

Accepted: July $24^{\text {th }}, 2020$

Available: September $30^{\text {th }}, 2020$

How to cite this article:

M. Hanefi Calp, Utku Kose, "Estimation of Burned Areas In Forest Fires Using Artificial Neural Networks," Revista Ingeniería Solidaria, vol. 16, no. 3, 2020. doi: https://doi.org/10.16925/2357-6014.2020.03.08

Artículo de investigación. https://doi.org/10.16925/2357-6014.2020.03.08

1 Department of Management Information Systems, Faculty of Economics \& Administrative Sciences, Karadeniz Technical University, Trabzon, Turkey

ORCID: https://orcid.org/0000-0001-7991-438X

E-mail: mhcalp@ktu.edu.tr

2 Department of Computer Engineering, Faculty of Engineering, Suleyman Demirel University, Isparta, Turkey

ORCID: https://orcid.org/0000-0002-9652-6415

E-mail: utkukose@sdu.edu.tr 


\section{Abstract}

Introduction: This article is the product of the research "Developing an Artificial Neural Network Based Model for Estimating Burned Areas in Forest Fires", developed at Karadeniz Technical University in the year 2020.

Problem: Forest Fires are an issue that greatly affect human life and the ecological order, leaving long-term issues. It should be estimated because it is not known when, where and how much the fire will be in the area.

Objective: The objective of the research is to use artificial neural networks to estimate the burned areas in forest fires.

Methodology: A feed-forward backpropagation neural network model was used for estimating the burned areas.

Results: We performed a performance evaluation over the proposed model by considering Regression values, Mean Absolute Percentage Error (MAPE) and Mean Square Error (MSE). The results show that the model is efficient in terms of its estimation of burnt areas.

Conclusions: The proposed artificial neural network model has a low error rate and high estimation accuracy. It is more effective than traditional methods for estimating burned areas in forests.

Originality: To the best of our knowledge, this is the first time that this real, unique data has been used for building and testing the model's estimations and the improvements that have been made in producing results faster and more accurately than with traditional methods.

Limitations: Since there are regional differences over different forest areas, effective criteria need to be analysed regarding the target regions.

Keywords: forest fires, burned areas, artificial neural networks, machine learning, estimation.

\section{Resumen}

Introducción: Este artículo es el producto de la investigación "Desarrollo de un modelo basado en redes neuronales artificiales para estimar áreas quemadas en incendios forestales", desarrollado en la Universidad Técnica de Karadeniz en el año 2020.

Problema: los incendios forestales son un problema que afecta en gran medida la vida humana y el orden ecológico, dejando problemas a largo plazo. Debe estimarse porque no se sabe cuándo, dónde y cuánto será el incendio en el área.

Objetivo: El objetivo de la investigación es utilizar redes neuronales artificiales para estimar las áreas quemadas en incendios forestales.

Metodología: Se usó un modelo de red neuronal de propagación hacia atrás para estimar las áreas quemadas. Resultados: Realizamos una evaluación de desempeño sobre el modelo propuesto considerando los valores de regresión, el error de porcentaje absoluto medio (MAPE) y el error de cuadrado medio (MSE). Los resultados muestran que el modelo es eficiente en términos de su estimación de áreas quemadas.

Conclusiones: El modelo de red neuronal artificial propuesto tiene una baja tasa de error y una alta precisión de estimación. Es más efectivo que los métodos tradicionales para estimar áreas quemadas en los bosques.

Originalidad: según nuestro conocimiento, esta es la primera vez que esta información real y única se ha utilizado para construir y probar las estimaciones del modelo y las mejoras que se han realizado para producir resultados más rápido y con mayor precisión que con los métodos tradicionales.

Limitaciones: Dado que existen diferencias regionales sobre las diferentes áreas forestales, es necesario analizar criterios efectivos con respecto a las regiones objetivo.

Palabras clave: incendios forestales, áreas quemadas, redes neuronales artificiales, aprendizaje automático, estimación. 


\section{Resumo}

Introdução: Este artigo é o produto da pesquisa "Developing an Artificial Neural Network Based for Estimativa de áreas queimadas em incêndios florestais ", desenvolvido na Universidade Técnica de Karadeniz no ano de 2020.

Problema: Os incêndios florestais são uma questão que afeta muito a vida humana e a ordem ecológica, deixando-os de longo prazo problemas. Deve ser estimado porque não se sabe quando, onde e quanto será o incêndio na área.

Objetivo: 0 objetivo da pesquisa é usar redes neurais artificiais para estimar as áreas queimadas em incêndios florestais.

Metodologia: Um modelo de rede neural de retropropagação de feed-forward foi usado para estimar as áreas queimadas.

Resultados: Realizamos uma avaliação de desempenho sobre o modelo proposto, considerando os valores de regressão, Erro percentual médio absoluto (MAPE) e erro quadrático médio (MSE). Os resultados mostram que o modelo é eficiente em termos de estimativa das áreas queimadas.

Conclusões: 0 modelo de rede neural artificial proposto tem baixa taxa de erro e alta precisão de estimativa. Isto é mais eficaz do que os métodos tradicionais para estimar áreas queimadas em florestas.

Originalidade: até onde sabemos, esta é a primeira vez que esses dados reais e únicos são usados para construir e testar as estimativas do modelo e as melhorias que foram feitas na produção de resultados mais rápida e com mais precisão do que com os métodos tradicionais.

Limitações: Uma vez que existem diferenças regionais em diferentes áreas florestais, critérios eficazes precisam ser analisados

em relação às regiões-alvo.

Palavras-chave: incêndios florestais, áreas queimadas, redes neurais artificiais, aprendizado de máquina, estimativa.

\section{INTRODUCTION}

Forests are very important natural resources that provide economic, ecological and sociocultural benefits such as preventing air pollution, adjusting the water order, contributing to the oxygen cycle, preventing erosion and landslides [1-4]. There are 1.31 billion hectares of intact forest land on earth and half of them are located in countries such as Canada, USA, Russia, China and Brazil [5]. These forest areas are threatened by many factors that endanger the continuity and vitality of the forest, such as drought, insect infestations, diseases, anthropogenic occupation and utilization, increased land use change, overgrazing and forest fires. Among these factors, forest fires, seen as an important problem, pose a risk to the continuity of forests in all regions of the world and lead to the complete disappearance of forest ecosystem functions $[6,7]$.

In this context, forest fire denotes an event where a forest has been destroyed by burning partially or completely. Forest fires are caused by natural events such as lightning strikes, electric lines touching each other, volcanic eruption, excessive 
temperature rises, and sometimes cigarette butts or fires that people start unconsciously. Forest fires occur in the forests of various parts of the world every year, causing firefighting costs reaching into the trillions of USD, loss of life, property and recreational spaces. Forest fires create negative effects, especially on the carbon cycle and other biogeochemical cycles, by affecting the growth, structure and location of forest lands and plants [8-10].

Since forest fires affect large areas and cause ecological, social and economic damage, it is of utmost importance to evaluate the burning risk of buildings during forest fires in order to reduce loss of life and property in the fire [11].

The characteristic features of large forest fires are that they spread to very large areas in a very short time due to unstable weather conditions, they cannot be controlled due to heavy winds and, as a result, they end only when they reach natural obstacles such as lakes, seas, large openings in forests and forestless areas [12]. It can occur over very large areas due to reasons such as weather conditions, the presence of flammable materials and the inability to intervene early. Determining the effects of weather conditions, such as hot, dry and windy, will help create systems that can predict the occurrence of small and large forest fires [5].

All these explanations and justifications clearly demonstrate the importance of the study. Nowadays, various methods have been proposed for determining forest fires and possible areas of burning. However, it can be said that the desired point is still not reached. In this context, the artificial neural networks approach, which is one of the artificial intelligence techniques and is also used in the study, was taken into consideration; artificial neural networks are used as an effective method for solving complex problems and especially for estimation.

Therefore, the purpose of this study is to estimate burned areas due to forest fires using artificial neural networks. The article is structured as follows: firstly, a literature review is presented, followed by the materials and methods of the study (artificial neural networks, obtaining and organizing data, creating the model etc.) being detailed in the second part; the findings and discussion can be found in the third part, and finally, the fourth part contains the results and suggestions obtained from the study.

\subsection{Literature review}

In the literature, many studies have been conducted on subjects such as forest fires, fire prevention, and the determination of burned areas. For example, Maeda et al. proposed a model that uses artificial neural networks and versatile images from MODIS (Moderate Resolution Imaging Spectroradiometer) / Terra-Aqua sensors to detect 
areas at high risk of forest fire. They stated that the artificial neural network model is a fast and relatively sensitive method for predicting forest fire events. As a result, they have demonstrated that the model offers a good alternative that reduces uncertainty in the currently used methods to support forest fire prevention policies and assist in the evaluation of burning areas [13].

Bisquert et al. estimated the forest fire hazard from remote sensing and fire history data using artificial neural networks and logistic regression. For this, they used MODIS images to obtain land surface temperature as the main input in forest fire hazard models in the Galicia region. Fire hazard has been classified and fire hazard maps based on this classification have made it easier to prevent and extinguish fires [14].

Elmas and Sönmez developed a forest fire prevention and management system by using artificial neural networks in order to protect existing forests. The system they developed predicts fires and the rate of spread of fires by grading the forest fire hazard. Thus, the system helps to develop correct strategies for fire prevention and combat before the fire, at the start of the fire and during the fire [15].

Cortez and Morais used the data mining technique to estimate the burned area of forest fires and tested their approach on real-world data. They stated that the SVM technique is effective for predicting the burn area of small fires that are more common. They also mentioned the importance of using different technical and predictive approaches, as large fires are rare events [16].

Karouni et al. aimed to predict and help make decisions on forest fires by using backpropagation on decision trees and advanced neural networks. For this, they used four sets of meteorological data: temperature, relative humidity, wind speed and daily precipitation. With the results of the study, they showed that high success was achieved and artificial neural network techniques were effective in such subjects [17].

Safi and Bouroumi proposed a model for the problem of predicting real forest fires using artificial neural networks. The proposed neural networks, the number of hidden layers and the number of neurons per layer is an intuitive multi-layer sensor. In this architecture, a backpropagation learning algorithm and a large real data set, related to the problem investigated, were used. In addition, they demonstrated the success of the study with the results showing the performance and usefulness of the resulting nervous system [18].

Anbaraoğlu proposed a model with support vector machines using data based on forest fires. The model is aimed at estimating the amount of burning area by including the spatial-temporal outsiders in the model with the model created. In order to reduce the dependence of the observed results to the selected data set, the data 
was compared to the original and derived data for 10 randomly selected data sets. As a result, the derived data appeared to be both less erroneous and more consistent [19].

Bozer estimated the size of the area lost due to fire by taking into account the burned areas caused by possible forest fires, the geographical conditions of the current environment, the date and time of the fire, meteorological data such as temperature, humidity and wind speed, and the type and number of trees in the unit area. Multilayer Sensors, Radial Basis Function Networks, Support Vector Machines and Fuzzy Logic techniques were used to make estimates. Thus, it provided a method for resource management in firefighting. The results showed that in some models, the performance in the estimation process is high and better than most of the studies available in the literature. The best result was obtained when using MLP [20].

Özkan et al. conducted research on multi-layer sensors, radial basis function and learning vector classification approaches for forest fire detection using SPOT-4. Adaboost and Logitboost algorithms were used for binary and multi-class classifications. It has been demonstrated that Adaboost and Logitboost classifications have great potential as an alternative to traditional techniques [21].

Liu et al. aimed to distinguish vegetation from burned and unburned areas via photon counting LiDAR data, thereby classifying burned areas. First of all, they emphasized the importance of mapping burned areas correctly, analysing carbon emissions and forest fire risk and understanding the effects of climate change on forest structure. As a result, the authors achieved high accuracy in the classification of burned forest areas. They also showed that the use of ICESat-2 data predicts burned biomass and carbon emissions better than the 3D perspective [22].

\section{MATERIALS AND METHODS}

In this context, the study was given under the following headings, respectively: artificial neural networks, obtaining and preparing of the data used in the study, and finally, creating of the ANN model (normalizing of the data, training and testing process). The general process followed to create the ANN model is given in Figure 1. 


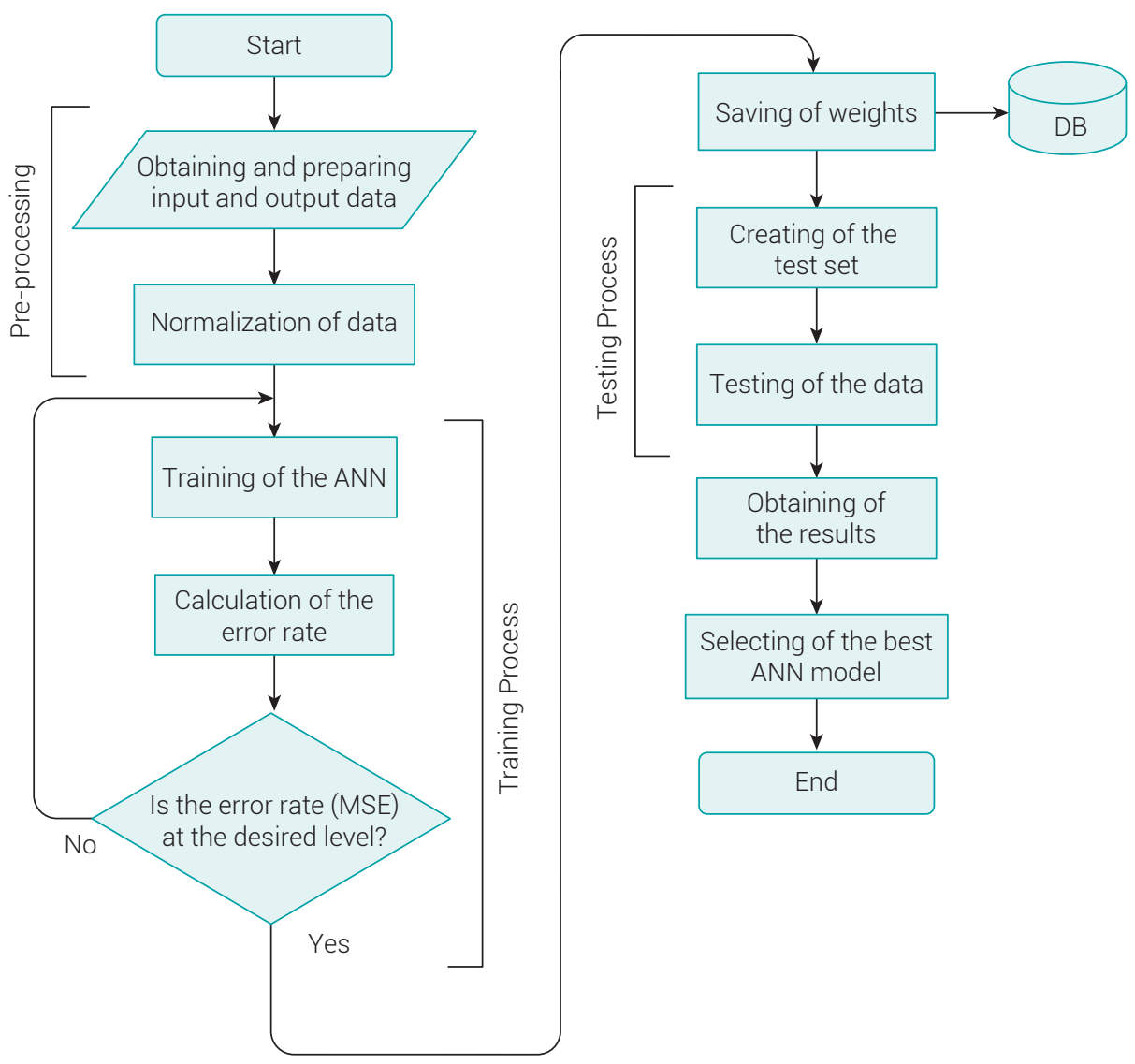

Figure 1. Flowchart used to create the ANN model.

Source: own work

\subsection{Artificial Neural Networks}

As artificial intelligence has become a critical technology in dealing with real-world problems $[23,24]$, the use of artificial neural networks is one of the strongest techniques used. Artificial neural networks are information processing systems that are widely used today, capable of performing the learning function by experimentation, which is the most basic feature of the human brain, and is capable of estimation. ANN has a structure that is different from traditional calculation techniques, adapts to the environment in which it is located and can decide in cases of uncertainty. ANN is used effectively in many different fields such as estimation, optical character handling, fingerprint recognition, pattern recognition, robot technology, job scheduling, quality control, power systems, system modelling, finance applications, image processing, industrial applications and defense applications [25-29]. 
A simple neural network is a structure consisting of a single neuron, very similar to biological neurons with dendrites and axons, with a single output node that connects to the input nodes and each input node. Figure 2 provides an example of how the development of artificial neural networks has been inspired by biological neural networks.

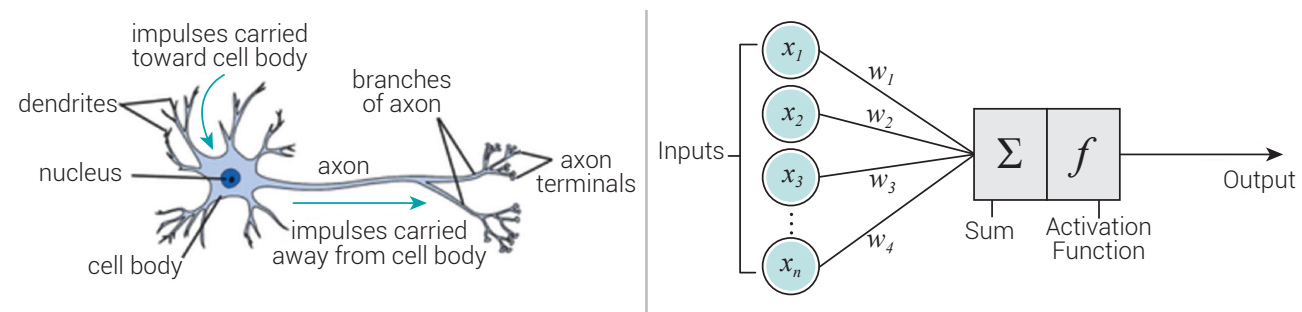

Figure 2. A simple ANN.

Source: [30]

At this point, a typical artificial neural network model can be defined mathematically as in Equation 1.

$$
u_{k}=\sum_{j=1}^{n} w_{k j} x_{j}, \mathrm{y}_{k}=\varphi\left(u_{k}+b_{k}\right), \mathrm{v}_{k}=u_{k}+b_{k}, \mathrm{y}_{k}=\varphi\left(v_{k}\right)
$$

ANN is used to solve nonlinear and complex problems. The data that makes up the model is divided into two sets; training and testing. During the training process, the error level is reduced by adjusting weights in the neural network, and this process continues until it reaches the targeted output. The performance of the model is obtained by testing the data that is never used in the training process on the neural network [31-33].

The feed-forward backpropagation neural network architecture is effective in the training of the network. The feed-forward neural network is arranged in cells-layers, and the outputs of cells in one layer are given as the input to the next layer via weights. The output of the network is determined by processing the information in the middle and output layer. With this structure, feed-forward networks perform a nonlinear static function. In the feed-forward neural network, the layer to which inputs are applied is called the input layer, the layer from which the outputs are received is 
the output layer, and the layer between the input and output layers is called the hidden layer. The number of neurons in the input and output layers is determined according to the needs of the problem addressed [34-36].

\subsection{Obtaining and Preparing the Data}

The data were taken from [37] and used in a study by Cortez and Morais [16]. This real data consisted of 517 lines in total. Since there was no data deviating from the normal data, noise removal operation had not been performed. Only, the month and day names were digitized. A sample dataset is given in Table 1.

Table 1. An example for the dataset

\begin{tabular}{ccccccccccccc}
\hline \multicolumn{1}{c}{ Inputs } & \multicolumn{1}{c}{ Output } \\
\hline $\mathbf{X}$ & $\mathbf{Y}$ & month & day & FFMC & DMC & DC & ISI & temp & RH & wind & rain & area \\
\hline 8 & 6 & 8 & 6 & 92.2 & 81.8 & 480.8 & 11.9 & 20.1 & 34 & 4.5 & 0 & 58.3 \\
\hline 4 & 6 & 9 & 7 & 93.5 & 149.3 & 728.6 & 8.1 & 28.3 & 26 & 3.1 & 0 & 64.1 \\
\hline 8 & 6 & 8 & 2 & 96.1 & 181.1 & 671.2 & 14.3 & 21.6 & 65 & 4.9 & 0.8 & 0 \\
\hline 4 & 4 & 9 & 3 & 92.9 & 133.3 & 699.6 & 9.2 & 26.4 & 21 & 4.5 & 0 & 88.49 \\
\hline 1 & 5 & 9 & 7 & 93.5 & 149.3 & 728.6 & 8.1 & 27.8 & 27 & 3.1 & 0 & 95.18 \\
\hline 7 & 5 & 8 & 2 & 96.1 & 181.1 & 671.2 & 14.3 & 27.3 & 63 & 4.9 & 6.4 & 10.8 \\
\hline 9 & 4 & 9 & 2 & 84.4 & 73.4 & 671.9 & 3.2 & 24.3 & 36 & 3.1 & 0 & 105.66 \\
\hline 5 & 4 & 8 & 5 & 91 & 166.9 & 752.6 & 7.1 & 21.1 & 71 & 7.6 & 1.4 & 2.17 \\
\hline 6 & 5 & 9 & 6 & 92.5 & 121.1 & 674.4 & 8.6 & 25.1 & 27 & 4 & 0 & 1090.84 \\
\hline 4 & 4 & 8 & 2 & 96.1 & 181.1 & 671.2 & 14.3 & 20.7 & 69 & 4.9 & 0.4 & 0 \\
\hline
\end{tabular}

Source: own work

\subsection{Creating the ANN Model}

Inputs and outputs were determined before creating the model. There are 13 titles in the model (12 inputs and 1 output). Inputs, outputs and attributes used in the model are given in Table 2. 
Table 2. Inputs, outputs and their explanations

\begin{tabular}{llll}
\hline No & $\begin{array}{c}\text { Inputs and } \\
\text { Output }\end{array}$ & \multicolumn{1}{c}{ Explanation } & Range \\
\hline 1 & $X$ & $\begin{array}{l}\text { Inputs } \\
\text { X-axis spatial coordinate within the } \\
\text { Montesinho park map }\end{array}$ & 1 to 9 \\
\hline 2 & $Y$ & $\begin{array}{l}\text { y-axis spatial coordinate within the } 9 \\
\text { Montesinho park map }\end{array}$ & $\begin{array}{l}\text { Since there are } 12 \text { months in a year, } \\
\text { it is numbered from } 1 \text { to } 12\end{array}$ \\
\hline 3 & month & month of the year: "jan" to "dec" & $\begin{array}{l}\text { Since there are } 7 \text { days in a week, it is } \\
\text { numbered from } 1 \text { to } 7\end{array}$ \\
\hline 5 & day & day of the week: "mon" to "sun" & 18.7 to 96.20 \\
\hline 6 & FFMC & FFMC index from the FWIt system & 1.1 to 291.3 \\
\hline 7 & DMC & DMC index from the FWI system & 7.9 to 860.6 \\
\hline 8 & DC & DC index from the FWI system & 0.0 to 56.10 \\
\hline 9 & ISI & ISI index from the FWI system & 2.2 to 33.30 \\
\hline 10 & temp & temperature in degrees Celsius & 15.0 to 100 \\
\hline 11 & RH & relative humidity in \% & 0.40 to 9.40 \\
\hline 12 & wind & wind speed in km/h & 0.0 to 6.4 \\
\hline
\end{tabular}

† FWI: Fire Weather Index, https://www.nwcg.gov/publications/pms437/cffdrs/fire-weather-index-system

Source: own work

\subsubsection{Normalization of the Data}

The data was normalized before the ANN model was created to scale the input and output values of the model, limit the data in the range of $0-1$, prevent unnecessary data duplication and thus increase the performance of the model to be created (Table 3). The "min-max" normalization method, which is widely used in the literature, was used to normalize the data. Here, $v_{R}$ represents the actual value of the input, $v_{\min }$ represents the minimum input value, and $v_{\max }$ represents the maximum input value (Equation 2) [35, 36, 38].

$$
V_{n}=\frac{V_{R}-V_{\min }}{V_{\max }-V_{\min }}
$$

An example of the normalized data before separating the training and test data is given in Table 3 . 
Table 3. An example for the normalized dataset

\begin{tabular}{ccccccccccccc}
\hline \multicolumn{10}{c}{ Inputs } \\
\hline $\mathbf{X}$ & $\mathrm{Y}$ & month & day & FFMC & DMC & DC & ISI & temp & RH & wind & rain & area \\
\hline 0.875 & 1.000 & 0.000 & 0.800 & 0.667 & 0.078 & 0.000 & 0.784 & 0.000 & 0.260 & 0.311 & 0.000 & 0.053 \\
\hline 0.375 & 1.000 & 1.000 & 1.000 & 0.778 & 0.705 & 0.912 & 0.441 & 1.000 & 0.100 & 0.000 & 0.000 & 0.059 \\
\hline 0.875 & 1.000 & 0.000 & 0.000 & 1.000 & 1.000 & 0.701 & 1.000 & 0.183 & 0.880 & 0.400 & 0.125 & 0.000 \\
\hline 0.375 & 0.000 & 1.000 & 0.200 & 0.726 & 0.556 & 0.805 & 0.541 & 0.768 & 0.000 & 0.311 & 0.000 & 0.081 \\
\hline 0.000 & 0.500 & 1.000 & 1.000 & 0.778 & 0.705 & 0.912 & 0.441 & 0.939 & 0.120 & 0.000 & 0.000 & 0.087 \\
\hline 0.750 & 0.500 & 0.000 & 0.000 & 1.000 & 1.000 & 0.701 & 1.000 & 0.878 & 0.840 & 0.400 & 1.000 & 0.010 \\
\hline 1.000 & 0.000 & 1.000 & 0.000 & 0.000 & 0.000 & 0.703 & 0.000 & 0.512 & 0.300 & 0.000 & 0.000 & 0.097 \\
\hline 0.500 & 0.000 & 0.000 & 0.600 & 0.564 & 0.868 & 1.000 & 0.351 & 0.122 & 1.000 & 1.000 & 0.219 & 0.002 \\
\hline 0.625 & 0.500 & 1.000 & 0.800 & 0.692 & 0.443 & 0.712 & 0.486 & 0.610 & 0.120 & 0.200 & 0.000 & 1.000 \\
\hline 0.375 & 0.000 & 0.000 & 0.000 & 1.000 & 1.000 & 0.701 & 1.000 & 0.073 & 0.960 & 0.400 & 0.063 & 0.000 \\
\hline
\end{tabular}

Source: own work

\subsubsection{Training and Testing Process}

The training and testing process were started after the data was normalized. These operations were carried out using the MATLAB package program. 75\% (388 data) for training and 25\% (129 data) for testing of randomly determined data from a total of 517 real data were allocated. Then, the training and testing processes were implemented to obtain the best ANN model. Many trials were made in different ways to create the model. The model (high $\mathrm{R}$ and low error rate) was determined as a result of experiments with different options such as different training functions, activation functions, transfer functions, different number of hidden layers and number of neurons in hidden layers. According to the findings obtained from these experiments, the attributes of the best model are given in Table 4.

Table 4. The attributes of the proposed ANN model.

\begin{tabular}{ccc}
\hline Dataset & Performance Criteria & Neural Network Model (12-8-8-1) \\
\hline Training & $\mathrm{R}$ & 0.99615 \\
\hline Testing & $\mathrm{R}$ & 0.99017 \\
\hline Validation & $\mathrm{R}$ & 0.99223 \\
\hline All & $\mathrm{R}$ & 0.99589 \\
\hline & MSE & 0.0021 \\
\hline
\end{tabular}

Source: own work 
The best ANN model, as a result of the trials after the data were trained, has the following features: the training $R$ ratio: 0.99615 , the test $R$ ratio: 0.99017 and the error rate is 0.0021 , and a multi-layered structure (12-8-8-1).

The values obtained were tested with test data to measure the memorization status and performance level of the model. The ANN model with a multi-layered structure is given in Figure 3 .

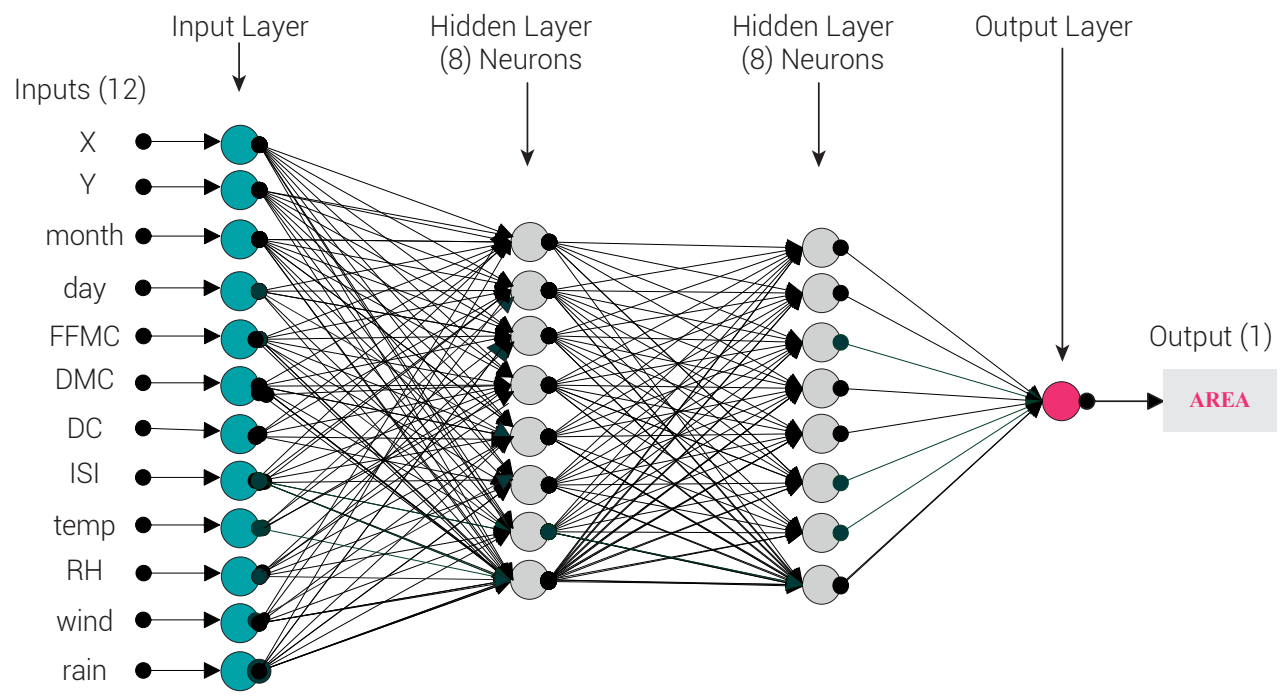

Figure 3. The proposed ANN model

Source: own work

\section{FINDINGS AND DISCUSSION}

The performance of the model was tested using real data after the model was created, and then the results obtained were analyzed. In the experimental process performed, it was observed that when the created model had a single hidden layer, low performance was achieved, but there was an increase in the performance of the model when it had two or more hidden layers. In addition, it was observed that the performance of the neural network model decreased significantly when the number of neurons in the hidden layer was increased, despite there being two hidden layers. In such a situation, it can be said that the model memorized or learned. 


\subsection{Experimental Results}

10 different burned areas were determined randomly in two different regions in order to measure the performance of the proposed model. The burned areas of each area were formed according to different input values, utilized real data and 20 rows in total. In Figure 4, examples of burned areas, some of which were highlighted with a white line, are given.

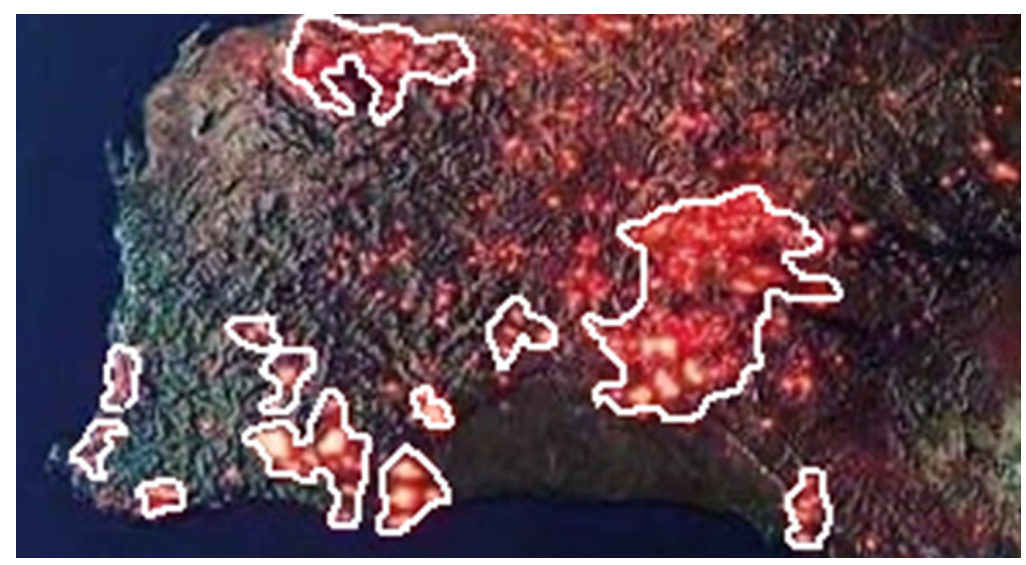

Figure 4. An example for burned areas Source: own work based on [39].

The Mean Absolute Percentage Error-MAPE (Eq.3), Mean Square Error-MSE (Eq.4) and Absolute Percentage Change- $R^{2}$ (Eq.5) formulas are commonly used to measure the estimated performance of network structures [40-43].

$$
\begin{aligned}
& M A P E=\frac{1}{T} \sum\left|\frac{y_{t}-\hat{y}_{t}}{y_{t}}\right| \times 100 \\
& M S E=\frac{1}{T} \sum_{t=1}^{T}\left(y_{t}-\hat{y}_{t}\right)^{2} \\
& R^{2}=1-\left(\frac{\sum_{t}\left(y_{t}-\hat{y}_{t}\right)^{2}}{\sum_{t}\left(\hat{y}_{t}\right)^{2}}\right)
\end{aligned}
$$

$$
\left(y_{t}=\text { Real Values, } y_{t}=\text { Estimated Values, } \mathrm{T}=\text { Number of Estimates }\right)
$$


The proposed model was tested by using the values of the burned areas that occurred according to the input values in the sample set. The experimental results were given and analyzed separately because they were taken from two different regions. The estimation results of the first randomly selected region are given in Table 5.

Table 5. The experimental results of the first region

\begin{tabular}{cccccc}
\hline No & Real Values & Estimated Values & MAPE & MSE & $\mathbf{R}^{\mathbf{2}}$ \\
\hline 1 & 0.001265 & 0.001145 & 0.01198 & 0.000000014 & 99.98802 \\
\hline 2 & 0.008113 & 0.007911 & 0.01999 & 0.000000041 & 99.98001 \\
\hline 3 & 0.016364 & 0.017250 & 0.08722 & 0.000000786 & 99.91278 \\
\hline 4 & 0.001430 & 0.001195 & 0.02346 & 0.000000055 & 99.97654 \\
\hline 5 & 0.005995 & 0.006123 & 0.01269 & 0.000000016 & 99.98731 \\
\hline 6 & 0.019195 & 0.019871 & 0.06628 & 0.000000456 & 99.93372 \\
\hline 7 & 0.004034 & 0.003950 & 0.00830 & 0.000000007 & 99.99170 \\
\hline 8 & 0.008498 & 0.008317 & 0.01790 & 0.000000033 & 99.98210 \\
\hline 10 & 0.002633 & 0.002210 & 0.04221 & 0.000000179 & 99.95779 \\
\hline & 0.010258 & 0.011394 & 0.11243 & 0.000001290 & 99.88757 \\
\hline
\end{tabular}

Source: own work

According to Table 5, it can be seen that high performance success rates were obtained when looking at the mean values: MAPE with a rate 0.07486 , MSE with a rate of 0.000001354 and $R^{2}$ with a rate of 99.92514 . The comparative representation of the real and estimated values obtained from the model is given in Figure $5 \mathrm{a}$ and the regression curve is given in Figure 5b. It can be seen that the estimation results obtained with the model, using real project data during the experiment period, were largely overlapping with real results and the error rates were very low (close to zero) (Figure 5). In other words, experimental results revealed that the performance of the model was high and the error rate was quite low. 

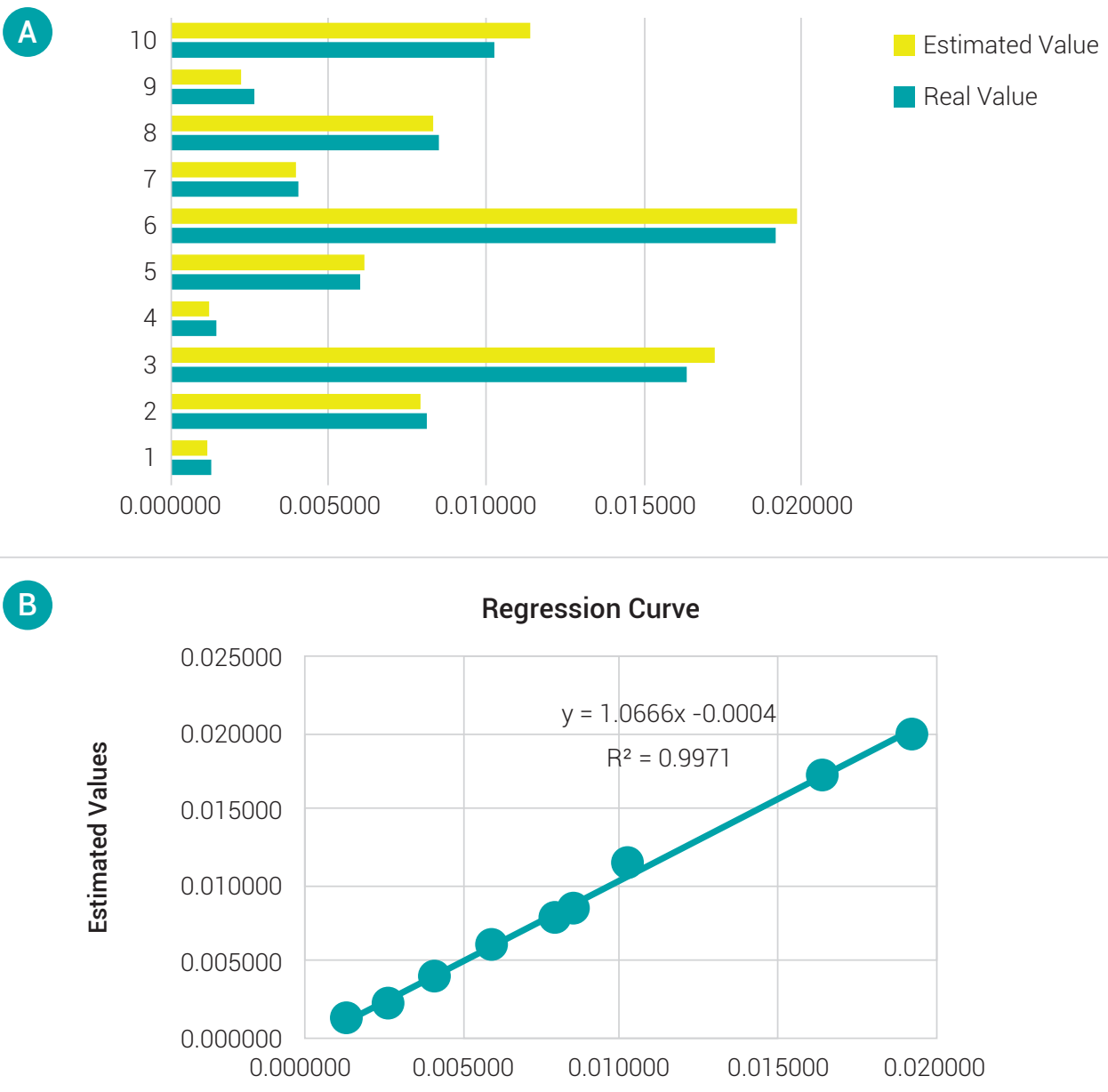

Real Values

Figure 5. The estimated results and regression curve for the first region Source: own work

The estimation results of the second randomly selected region are given in Table 6.

Table 6. The experimental results of the second region

\begin{tabular}{cccccc}
\hline No & Real Value & Estimated Value & MAPE & MSE & $\mathbf{R}^{\mathbf{2}}$ \\
\hline 1 & 0.054445 & 0.047562 & 0.65274 & 0.000047372 & 99.34726 \\
\hline 2 & 0.587621 & 0.540125 & 2.99162 & 0.002255827 & 97.00838 \\
\hline 3 & 0 & 0.011825 & 1.18250 & 0.000139831 & 98.81750 \\
\hline 4 & 0.381121 & 0.439852 & 4.25242 & 0.003449334 & 95.74758 \\
\hline & & & & (continúa)
\end{tabular}


(viene)

\begin{tabular}{cccccc}
\hline No & Real Value & Estimated Value & MAPE & MSE & $\mathbf{R}^{\mathbf{2}}$ \\
\hline 5 & 0.077254 & 0.090014 & 1.18453 & 0.000162828 & 98.81547 \\
\hline 6 & 0.049901 & 0.042872 & 0.66949 & 0.000049407 & 99.33051 \\
\hline 7 & 0.196861 & 0.210039 & 1.10101 & 0.000173649 & 98.89899 \\
\hline 8 & 0.019893 & 0.020148 & 0.02496 & 0.000000065 & 99.97504 \\
\hline 9 & 1 & 0.96204 & 1.89800 & 0.001440962 & 98.10200 \\
\hline 10 & 0.255335 & 0.229758 & 2.03746 & 0.000654183 & 97.96254 \\
\hline \multicolumn{7}{c}{ Mean Values } & & $\mathbf{1 . 5 9 9 4 7}$ & $\mathbf{0 . 0 0 0 8 3 7 3 4 6}$ & $\mathbf{9 8 . 4 0 0 5 3}$ \\
\hline
\end{tabular}

Source: own work

According to Table 6, high performance rates were also obtained in the second region, as in the first region. That is: MAPE with a rate of 1.59947, MSE with a rate of 0.000837346 and $R^{2}$ with a ratio of 98.40053 . The comparative representation of the real and estimated values obtained from the model is given in Figure $6 a$ and the regression curve is given in Figure 6b. In Figure 6, it can be seen that the estimation performance obtained by using the model was high and the error rate was quite low, as in Figure 5.

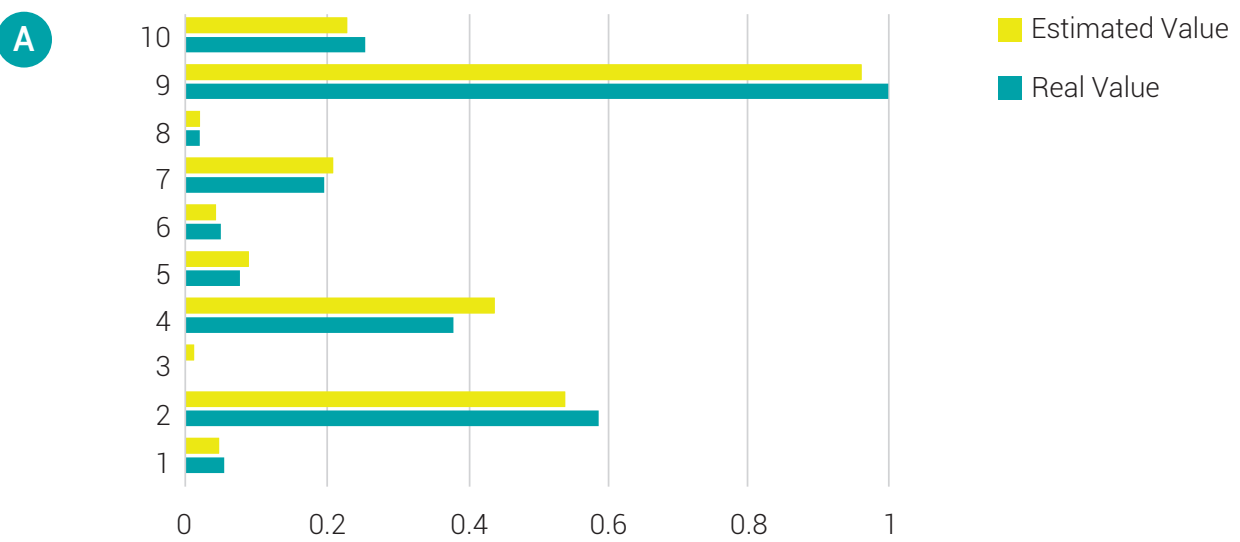




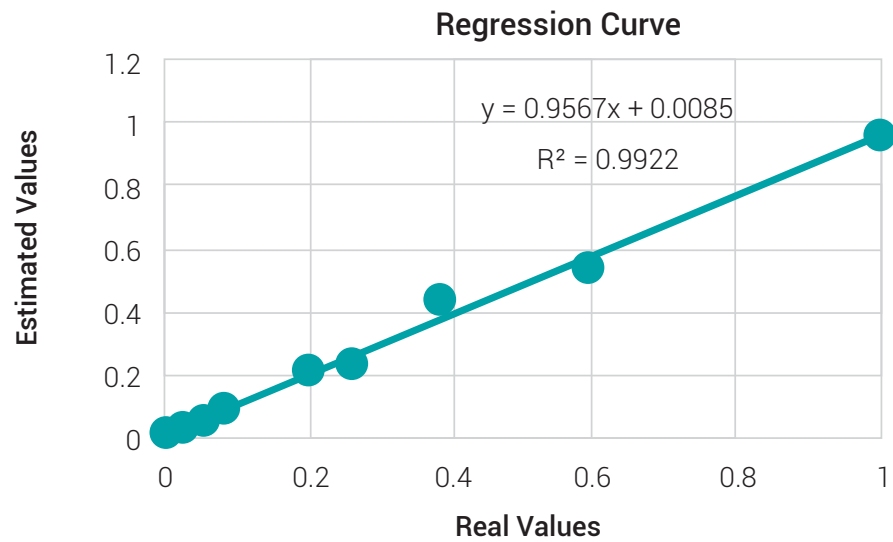

Figure 6. The estimated results and regression curve for the second region Source: own work

As a result, the estimation results obtained by using burned area values, determined from both regions, clearly revealed the success of the study.

\section{CONCLUSION AND RECOMMENDATIONS}

In this study, a neural network model was proposed that estimates burned areas in forest fires using artificial neural networks. The model has twelve inputs, two hidden layers (8 neurons) and one output. At this point, one of the most important points to be considered while creating the neural network is to determine the number of hidden layers. The performance of the model was measured using real data for both regions after the model was created. Experimental results showed that the performance of the proposed model was quite good and the error rate was low.

The study clearly demonstrated the importance of using up-to-date techniques on important topics such as forest fires, which have been difficult to predict, rather than traditional approaches. However, hybrid approaches can be used by adding different techniques to minimize the error rate with successful estimation results being obtained by using the artificial neural network technique. The study is considered to be very important because it demonstrated the abilities to eliminate or prevent major damages that may occur by using the predictive feature of artificial neural networks. 


\section{REFERENCES}

[1] E. Omer and D. M. Abdurrahmanoglu, "Analysis of Costs on Fighting Against Forest Fires: An Example of Kahramanmaras Forest Regional Directorate (In Turkish)," Turkish Journal of Forest Science, vol. 2, no. 1, pp. 34-48, 2018. [Online]. doi: 10.32328/turkjforsci.400491.

[2] B. Marcolla, A. Cescatti, L. Montagnani, G. Manca, G. Kerschbaumer, and S. Minerbi, "Importance of advection in the atmospheric CO2 exchanges of an alpine forest," Agricultural and Forest Meteorology, vol. 130, no. 3-4, pp. 193-206, 2005. [Online]. doi: 10.1016/j.agrfor met.2005.03.006.

[3] H. Jactel, J. Bauhus, J. Boberg, D. Bonal, B. Castagneyrol, B. Gardiner and E. G. Brockerhoff, "Tree diversity drives forest stand resistance to natural disturbances," Current Forestry Reports, vol. 3, no. 3, pp. 223-243, 2017. [Online]. doi: 10.1007/s40725-017-0064-1.

[4] A. Romano, A. Costa, S. Salvidio, M. Menegon, E. Garollo, K. T. de Fatis and P. Pedrini, "Forest management and conservation of an elusive amphibian in the Alps: Habitat selection by the Golden Alpine Salamander reveals the importance of fine woody debris," Forest Ecology and Manag., vol. 424, pp. 338-344, 2018. [Online]. doi: 10.1016/j.foreco.2018.04.052.

[5] M. Turkes and G. Altan, "Meteorological and Hydro-Climatological Analysis of Large Forest Fires of Çanakkale in the Year of 2008 (In Turkish)," SSRN Electronic Journal, vol. 10, no. 2, pp. 195-218, 2012. [Online]. doi: 10.2139/ssrn.3394247.

[6] M. Demir, A. Kucukosmanoglu, M. Hasdemir, H. Acar and T. Ozturk, "Assessment of forest roads and firebreaks in Turkey," African Journal of Biotechnology, vol. 8, no. 18, pp. 4553-4561, 2009. [Online]. doi: 10.5897/AJB09.396.

[7] N. Kuter, F. Yenilmez and S. Kuter, "Forest fire risk mapping by kernel density estimation," Croatian Journal of Forest Engineering: Journal for Theory and Application of Forestry Engineering, vol. 32, no. 2, 599-610, 2011. [Online]. doi: https://hrcak.srce.hr/72661.

[8] M. Zile, "Analysis of the Realized Forest Fire in the Event, Determination of the Defects and the Precautions That Must Be Performed (In Turkish)," Anatolian Journal of Forest Research, vol. 4, no. 2, pp. 89-97, 2018.

[9] M. Turkes and G. Altan, "Analysis of the year 2008 fires in the forest lands of the Muğla Regional Forest Service by using drought indices (In Turkish)," International Journal of Human Sciences, vol. 9, no. 1, pp. 912-931, 2012. 
[10] G. Altan, Climatological and meteorological analysis of large forest fires that took place in the 2000-2008 period in Mugla and Canakkale provinces (In Turkish). MSc. Thesis, Canakkale Onsekiz Mart Univ., Institute of Social Sciences, Canakkale, Turkey, 2011.

[11] E. Yilmaz, A. Kayacan and K. H. Guler, "A wildfire hazard rating model for residential structures within and around the forest areas: The case of Antalya Forestry Regional Directorate (In Turkish)," Turkish Journal of Forestry Research, vol. 6, no. 1, pp. 1-14, 2018. [Online]. doi: 10.17568/ogmoad.425476.

[12] U. Baltaci and F. Yildirim, "Forecasting risky years for forest fires depending on sunspot cycle (In Turkish)," Turkish Journal of Forestry Research, vol. 4, no. 2, pp. 133-142, 2017. [Online]. doi: 10.17568/ogmoad.338404.

[13] E. E. Maeda, A. R. Formaggio, Y. E. Shimabukuro, G. F. B. Arcoverde and M. C. Hansen, "Predicting forest fire in the Brazilian Amazon using MODIS imagery and artificial neural networks," International Journal of Applied Earth Observation and Geoinformation, vol. 11, no. 4, pp. 265-272, 2009. [Online]. doi: 10.1016/j.jag.2009.03.003.

[14] M. Bisquert, E. Caselles, J. M. Sánchez and V. Caselles, "Application of artificial neural networks and logistic regression to the prediction of forest fire danger in Galicia using MODIS data," International Journal of Wildland Fire, vol. 21, no. 8, pp. 1025-1029, 2012. [Online]. doi: 10.1071/WF11105.

[15] C. Elmas and Y. Sonmez, "Enhancing the Data Fusion Based Forest Fire Preserving and Management System (In Turkish)," Journal of Polytechnic, vol. 11, no. 2, pp. 99-108, 2008.

[16] P. Cortez and A. Morais, A Data Mining Approach to Predict Forest Fires using Meteorological Data. In J. Neves, M. F. Santos and J. Machado Eds., New Trends in Artificial Intelligence, Proceedings of the 13th EPIA 2007 - Portuguese Conference on Artificial Intelligence, December, Guimaraes, Portugal, pp. 512-523, 2007. APPIA, 2007.

[17] A. Karouni, B. Daya and P. Chauvet, "Applying decision tree algorithm and neural networks to predict forest fires in Lebanon," Journal of Theoretical and Applied Information Technology, vol. 63, pp. 282-291, 2014.

[18] Y. Safi and A. Bouroumi, "Prediction of forest fires using artificial neural networks," Applied Mathematical Sciences, vol. 7, no. 6, pp. 271-286, 2013.

[19] B. Anbaroglu, Modeling Forest Fires by Considering Spatial-Temporal Outside Elements (In Turkish). 2nd Remote Sensing and Geographic Information Systems Symposium (UZAL-CBS 2008), Kayseri, Turkey. [Online]. Available: http://uzalcbs.org/wp-content/uploads/2016/11/2008_06.pdf (Retrieved 20.04.2020). 
[20] A. M. Ozbayoglu and R. Bozer, "Estimation of the burned area in forest fires using computational intelligence techniques," Procedia Computer Science, vol. 12, pp. 282-287, 2012. [Online]. doi: 10.1016/j.procs.2012.09.070.

[21] C. Ozkan, F. Sunar, S. Berberoglu and C. Donmez, Effectiveness of boosting algorithms in forest fire classification. The International Archives of the Photogrammetry, Remote Sensing and Spatial Information Sciences, vol. 37, 2008. Part B7. Beijing, China.

[22] M. Liu, S. Popescu and L. Malambo, "Feasibility of Burned Area Mapping Based on ICESAT2 Photon Counting Data," Remote Sensing, vol. 12, no. 1, pp.24, 2020. [Online]. doi: doi. org/10.3390/rs12010024.

[23] V. C. Muller, Philosophy and theory of artificial intelligence. Berlin: Springer, 2018.

[24] Cevizoglu, H, "Artificial Intelligence, Philosophy of Technology and Social Life (In Turkish)," in Artificial Intelligence and Future, G. Telli, Ed. Istanbul: Dogu, 2019.

[25] M. H. Calp, "An Estimation of Personnel Food Demand Quantity for Businesses by Using Artificial Neural Networks (In Turkish)," Journal of Polytechnic, vol. 22, no. 3, pp. 675-686, 2019. [Online]. doi: 10.2339/politeknik.444380.

[26] S. A. Kalogirou and M. Bojic, "Artificial neural networks for the prediction of the energy consumption of a passive solar building," Energy, vol. 25, no. 5, pp. 479-491, 2000. [Online]. doi: 10.1016/S0360-5442(99)00086-9.

[27] S. Bayram, K. Kaplan, M. Kuncan, H. M. Ertunc, Ball Bearings space of time Statistical Feature Extraction and Neural Networks with Error Estimation Method Size, Automatic Control National Meeting, TOK2013, Malatya, Turkey. 26-28 September, 2013.

[28] A. Ugur and A. C. Kinaci, Classification of web pages with artificial intelligence techniques and artificial neural networks (In Turkish). 11th Conference of Internet in Turkey, 362, 2006.

[29] M. H. Calp and M. A. Akcayol, A Novel Model for Risk Estimation in Software Projects Using Artificial Neural Network. In: Hemanth D., Kose U. (eds) Artificial Intelligence and Applied Mathematics in Engineering Problems. ICAIAME 2019. Lecture Notes on Data Engineering and Communications Technologies, vol 43. Springer, Cham, 2020. [Online]. doi: 10.1007/978-3-030-36178-5_23.

[30] K. Willems, Keras Tutorial: Deep Learning in Python, 2019. [Online]. Available: https://www. datacamp.com/community/tutorials/deep-learning-python (Retrieved 26.04.2020). 
[31] S. Neseli, S. Tasdemir and S. Yaldiz, "Estimation of surface roughness on turning with Artificial Neural Network," Journal of Engineering and Architecture Faculty of Eskisehir Osmangazi University, vol. 22, no. 3, pp. 65-75, 2009.

[32] D. Askin, I. Iskender and A. Mamizadeh, "Dry type transformer winding thermal analysis using different neural network methods," Journal of the Faculty of Engineering and Architecture of Gazi University, vol. 26, no. 4, pp. 905-913, 2011.

[33] C. Karatas, A. Sozen and E. Dulek, "Modelling of residual stresses in the shot peened material C-1020 by artificial neural network," Expert Systems with Applications, vol. 36, no. 2, pp. 35143521, 2009. [Online]. doi: 10.1016/j.eswa.2008.02.012.

[34] M. Firat and M. Gungor, "Determination of Carried Suspended Sediment Concentration and Amount by Artificial Neural Networks (In Turkish)," IMO Technical Journal, vol. 15, no. 73, 2004.

[35] M. H. Calp, Artificial Intelligence Based Risk Managementfor Software Projects (In Turkish), PhD. Thesis, Gazi University, Institute of Informatics, Management Information Systems, Ankara, Turkey, 2017.

[36] H. Erdal, "Contribution of Machine Learning Methods to the Construction Industry: Estimation of Compressive Strength," Pamukkale University Journal of Engineering Sciences, vol. 21, no. 3 , pp. 109-114, 2015. [Online]. doi: 10.5505/pajes.2014.26121.

[37] D. Dua and C. Graff, UCl Machine Learning Repository. [Online]. Available: http://archive.ics. uci.edu/ml. Irvine, CA: University of California, School of Information and Computer Science, 2019.

[38] M. Deveci, Artificial Neural Networks and Used of Waiting Time Estimation (In Turkish). MSc. Thesis, Gazi University, Institute of Social Sciences, Ankara, Turkey, 2012.

[39] K. Orakcioglu, We are inviting the fires (In Turkish). Pazarlama Turkiye Web Site, 2020. [Online]. Available: https://pazarlamaturkiye.com/yanginlara-davetiye-cikariyoruz-avustralya/

[40] M. H. Calp, "A Hybrid ANFIS-GA Approach for Estimation of Regional Rainfall Amount," Gazi University Journal of Science, vol. 32, no. 1, pp. 145-162, 2019.

[41] H. Gandomi and D. A. Roke, "Assessment of artificial neural network and genetic programming as predictive tools," Advances in Engineering Software, vol. 88, pp. 63-72, 2015. [Online]. doi: 10.1016/j.advengsoft.2015.05.007. 
22 Estimation of Burned Areas In Forest Fires Using Artificial Neural Networks

[42] S. Marinai, M. Gori and Soda, G., "Artificial neural networks for document analysis and recognition," IEEE Transactions on Pattern Analysis and Machine Intelligence, vol. 27, no. 1, pp. 23-35, 2005. [Online]. doi: 10.1109/TPAMI.2005.4.

[43] Y. Bengio, "Learning deep architectures for Al," Foundations and Trends in Machine Learning, vol. 2, no. 1, pp. 1-127, 2009. [Online]. doi: 10.1561/2200000006. 